\title{
The Use of Ion Exchange Resin for Reagent Immobilization and Concentration in Flow Systems. Determination of Nickel in Steel
}

\author{
Alloys and Iron Speciation in Waters \\ Patrícia B. Martelli ${ }^{a}$, Boaventura F. Reis ${ }^{b}$, Mauro Korn ${ }^{c}$, \\ and Iolanda A. Rufini ${ }^{b}$ \\ ${ }^{a}$ Instituto de Química de São Carlos, Universidade de São Paulo, São Carlos - SP, Brazil \\ ${ }^{b}$ Centro de Energia Nuclear na Agricultura, Universidade de São Paulo, C.P. 96, \\ 13400-970 Piracicaba - SP, Brazil \\ ${ }^{c}$ Universidade do Estado da Bahia, Salvador, Brazil
}

Received: May 13, 1996; June 17, 1997

\begin{abstract}
Neste trabalho, foi investigado o emprego de persulfato de potássio imobilizado em resina aniônica AG1-X8, como agente oxidante, na determinação espectrofotométrica de níquel em ligas metálicas, e na especiação de Fe (III)/Fe (II) em águas de rio, utilizando-se sistema de análise em fluxo. O diagrama de fluxo foi desenvolvido para que a oxidação da espécie de interesse e o recondicionamento da resina pudessem ser efetuados em linha. A determinação de níquel baseou-se no método da dimetilglioxima, apresentando uma freqüência analítica de 80 determinações por hora. Com este sistema, obteve-se um baixo consumo de reagentes, $10 \mathrm{mg}(200 \mu \mathrm{L})$ de persulfato de potássio e 8,0 $\mu \mathrm{g}(133 \mu \mathrm{L})$ de dimetilglioxima por determinação. Para uma solução de amostra contendo $21,5 \%(\mathrm{~m} / \mathrm{m})$ de $\mathrm{Ni}$, encontrou-se um desvio padrão relativo de $1 \%(\mathrm{n}=10)$. Aplicando-se o teste- $t$ pareado, obteve-se uma concordância com $95 \%$ de confiança entre os resultados do sistema proposto e os obtidos com espectrofotometria de absorção atômica com chama. Na determinação de Fe (III), utilizou-se tiocianato de potássio como reagente cromogênico, alcançando-se uma frequência analítica de 60 determinações por hora. O método apresentou um consumo de reagentes de $3,5 \mathrm{mg}(70 \mu \mathrm{L})$ persulfato de potássio e de $5,4 \mathrm{mg}(270 \mu \mathrm{L})$ de tiocianato de potássio por determinação. O desvio padrão relativo calculado para uma solução de amostra contendo $3,17 \mathrm{mg}$ $\mathrm{L}^{-1}$ de $\mathrm{Fe}(\mathrm{III})$ foi de $1,5 \%(\mathrm{n}=10)$. Os resultados empregando-se o método proposto para $\mathrm{Fe}$ (II) foram comparados com aqueles obtidos com o método espectrofotométrico, baseado na reação com 1,10 - fenantrolina, apresentando uma concordância com nível de confiança de $95 \%$.
\end{abstract}

Flow injection systems employing potassium peroxydisulphate as oxidizing reagent, immobilized on the anionic exchange resin AG1-X8 are proposed for spectrophotometric determination of nickel in steel alloys and for the speciation of iron (III)/iron (II) in waters. The flow networks were designed to provide facilities to perform on line analyte oxidation and resin reconditioning steps. The feasibility was ascertained by determining nickel in acid solutions of steel alloys and performing speciation of iron (III)/iron (II) in waters, using as chromogenic reagents dimethylglyoxime for nickel and potassium thiocyanate for iron. Profitable features such as a throughput of 80 and 60 samples per hour, 1.0 and $1.5 \%(\mathrm{n}=10)$ as relative standard deviations for nickel $(21.5 \% \mathrm{~m} / \mathrm{m})$ and iron (III) $\left(3.17 \mathrm{mg} \mathrm{L}^{-1}\right)$, low reagents consumption (10 and $3.5 \mathrm{mg}$ of potassium peroxydisulphate, $8.0 \mu \mathrm{g}$ dimethylglyoxime and $5.4 \mathrm{mg}$ of potassium thiocyanate, for nickel and iron, respectively) were observed. The accuracy for both procedures were ascertained by applying paried $t$-test between results obtained with flame atomic absorption spectrophotometry (FAAS) for Ni and 1,10-phenantroline spectrophotometric method for Fe (II), and no significant difference at $95 \%$ confidence level were observed.

Keywords: flow analysis, immobilized reagent, chemical speciation, steel alloys 


\section{Introduction}

Nickel is an important constituent of several steel alloys. Its determination is required to control both raw material and industrial products, and has been usually performed by atomic emission or absorption spectrometry ${ }^{1,2}$ or molecular absorption spectrophotometry ${ }^{3}$. Dimethylglyoxime is a widely reagent used for spectrophotometric determination of nickel in aqueous solutions, producing in alkaline (mainly ammoniacal) medium a water soluble compound detected at $460 \mathrm{~nm}^{3,4}$. Potassium peroxydisulphate has been generally used as oxidizing reagent, and should be added to the sample following the addition of the dimethylglyoxime solution ${ }^{4}$. In earlier work ${ }^{5}$, the authors observed that potassium peroxydisulphate concentration exerted a remarkable effect on the magnitude of the analytical signal. Since potassium peroxydisulphate solutions with concentrations larger than $5 \%$ are difficult to be achieved, therefore, a strategy to increase the peroxydisulphate concentration available for the oxidation process should be appreciated.

Reagents in solid phase or immobilized on appropriated surfaces have been used in flow injection systems, in order to accomplish several analytical requirements ${ }^{6}$. Columns packed with solid reagents have been employed to convert nitrate to nitrite ${ }^{7}$, ammonium to ammonia ${ }^{8}$ etc. Also, reagents adsorbed on surface such as silica have been used to improve selectivity ${ }^{9-11}$.

Anionic exchange resins have been coupled to the flow network to perform on line preconcentration and separation $^{12,13}$. As they present the ability to adsorb ligands and metallic anionic complexes as well, its use has been proposed to enhance selectivity ${ }^{14}$. Some anionic resins, such as AG1-X8, present a high capacity to adsorb anions, therefore when they are saturated with a specific chemical species, its availability on the resin column may be much higher than in solution. This feature suggests a possibility for increasing amount of reagent, when its availability is limited by low solubility in water.

Speciation of iron (III)/iron (II) is interest in studies concerning water pollution ${ }^{15}$. The ratio between the concentrations of these two chemical species undergoes changes with time, therefore it is mandatory their simultaneous determination. Considering that thiocyanate reacts with iron (III) ions producing a colored compound but not with iron (II) ions ${ }^{4}$, it is possible to design a flow manifold for the simultaneous determination of iron (III) and iron (II) in waters, coupling a resin column loaded with peroxydisulphate anions to the flow network in order to perform on line oxidation of iron (II) to iron (III).

This work investigates the possibility of employing an anionic resin column loaded with peroxydisulphate ions, coupled to a flow network, in order to increase reagent amount available for oxidation step. The effectiveness of the approach was ascertained by spectrophotometric determination of nickel in steel alloys and iron (III)/iron (II) in waters, using dimethylglyoxime and potassium thiocyanate as chromogenic reagents.

\section{Experimental}

\section{Apparatus}

The flow set up consisted of a 432 Femto (São Paulo, Brasil) spectrophotometer with a flow cell $(180 \mu \mathrm{L}$ inner volume, $12 \mathrm{~mm}$ optical path), coupled to a REC 61 Radiometer strip chart recorder, an Ismatec IPC-8 peristaltic pump, with Tygon pumping tubes of different inner diameters, a home made automatic injector designed as described in the next section, three-way solenoid valves ${ }^{5}$, coiled reactors and flow lines of polyethylene tubing $(0.8 \mathrm{~mm}$ inner diameter), a resin column (10 $\mathrm{mm}$ long, $4 \mathrm{~mm}$ i.d) machined in perspex as described elsewhere ${ }^{12}$, a 486 microcomputer equipped with an interface PCL-771S Advantech Corp. and other needful electronic interface ${ }^{5}$. The microcomputer run a software written in Quick Basic 4.5, which controlled injector and solenoid valves.

\section{Solutions}

The solutions were prepared from analytical grade reagents and freshly distilled-deionized water.

The $0.6 \%(\mathrm{~m} / \mathrm{v})$ dimethylglyoxime solution was prepared by dissolution an appropriate amount of reagent in $250 \mathrm{~mL}$ of a $2.0 \mathrm{~mol} \mathrm{~L}^{-1} \mathrm{NaOH}$ solution. The $3.0 \%(\mathrm{v} / \mathrm{v})$ triethanolamine solution was prepared by dilution of $3 \mathrm{~mL}$ of reagent up to $100 \mathrm{~mL}$ with water. The $5.0 \%(\mathrm{~m} / \mathrm{v})$ potassium peroxydisulphate solution was prepared by dissolving $5.0 \mathrm{~g}$ of the compound in $100 \mathrm{~mL}$ of water at $80{ }^{\circ} \mathrm{C}$ and stirring until its complete dissolution. The $2.0 \%(\mathrm{~m} / \mathrm{v})$ potassium thiocyanate solution was prepared by dissolving $4.0 \mathrm{~g}$ of reagent in $200 \mathrm{~mL}$ of water.

The nickel standard stock solution was prepared by dissolving $1.000 \mathrm{~g}$ of metallic nickel in $14 \mathrm{~mL}$ of concentrated $\mathrm{HNO}_{3}$ and making the volume up to $1000 \mathrm{~mL}$ with water. Analytical solutions of 0.00, 5.00, 10.0, 20.0 and $30.0 \mathrm{mg} \mathrm{L}^{-1}$ were prepared by appropriate dilutions of the stock solution in $0.5 \mathrm{~mol} \mathrm{~L}^{-1} \mathrm{HCl}$ in the presence of $200 \mathrm{mg} \mathrm{L}^{-1}$ iron (III).

The iron (III) stock solution, $1000 \mathrm{mg} \mathrm{L}^{-1}$, was prepared by dissolution of $1.000 \mathrm{~g}$ of metallic iron in $20 \mathrm{~mL} \mathrm{HCl}-$ $\mathrm{HNO}_{3}$ (1:1) and warming gently up to complete dissolution, after cooling, the volume was made up to $1000 \mathrm{~mL}$ with water. Iron (II) stock solution, $1000 \mathrm{mg} \mathrm{L}^{-1}$, was prepared by dissolving $0.996 \mathrm{~g}$ of ferrous sulphate heptahydrate in $200 \mathrm{~mL}$ of water. Analytical solutions of 0.00 , $1.00,2.00,4.00,6.00,8.00$ and $10.0 \mathrm{mg} \mathrm{L}^{-1}$ for Fe (II) and Fe (III) were prepared by appropriate dilutions of respective stock solutions, with $0.014 \mathrm{~mol} \mathrm{~L}^{-1} \mathrm{HNO}_{3}$ solution. 
Alloy samples for nickel determination were prepared by weighing about $500 \mathrm{mg}$ of scraps, dissolving in $15 \mathrm{~mL}$ of concentrated $\mathrm{HCl}$ plus $5 \mathrm{~mL}$ of concentrated $\mathrm{HNO}_{3}$, and gently heating up to $95^{\circ} \mathrm{C}$ until complete dissolution. After cooling, the volume was made up to $250 \mathrm{~mL}$ with water.

The samples for iron speciation were collected in several sites of the Piracicaba river and analyzed in the same day. At the collection, samples were filtered through 0.45 $\mu \mathrm{m}$ membrane filters and $1 \mathrm{~mL}$ of concentrated $\mathrm{HNO}_{3}$ was added per litre of sample ${ }^{16}$.

The column was packed with AG1-X8 resin (200-400 mesh) and saturated with peroxydisulphate anion just before use, by pumping through it a $5.0 \%(\mathrm{~m} / \mathrm{v})$ potassium peroxydisulphate solution at $2.0 \mathrm{~mL} \mathrm{~min}^{-1}$ during $15 \mathrm{~min}$.

\section{Flow diagrams and flow procedure}

The flow networks were designed considering that resin loading and oxidizing steps should be performed on line. In this case, an injector with an appropriated configuration was designed, and details concerning its construction are shown in Fig. 1. The main body of the injector was machined in perspex and the three pieces were assembled together by means of screws with springs. With this mounting, a tight adjustment was achieved in order to avoid fluid linkage between surface contacts, thus allowing the central piece to slide easily from sampling to injection position and vice-versa. Commutation was carried out by two $10 \mathrm{~W}$ solenoids, attached to injector sliding bar by means of a lever and controlled by a microcomputer. The solenoid attachment was omitted in the figure to simplify the design. Although the flow networks for nickel determination and

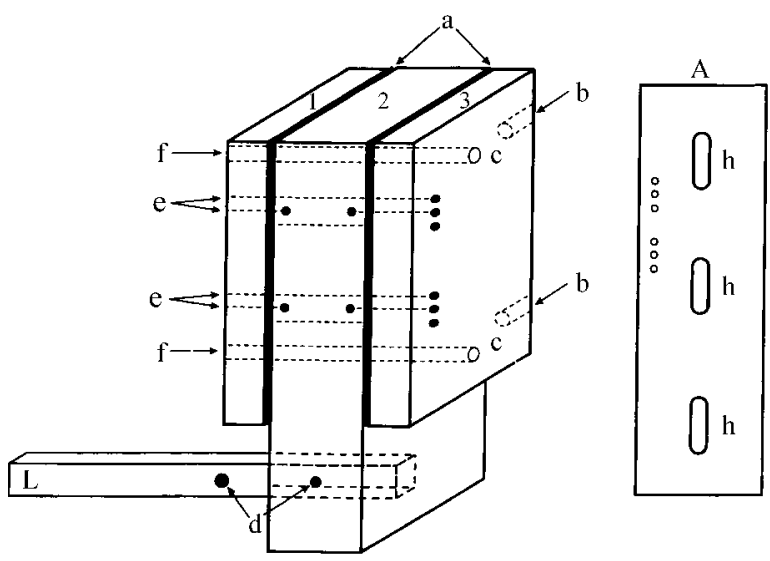

Figure 1. The injector commutator. Injector body perspex plates with dimensions $100 \times 45 \times 12 \mathrm{~mm}$ for 1 and 3 , and $120 \times 45 \times 20 \mathrm{~mm}$ for 2 ; $\mathrm{a}=$ rubber gasket; $\mathrm{b}=$ screw thread; $\mathrm{c}=$ lead hole for screw, $\mathrm{d}=$ pivot; $\mathrm{f}=$ screw thread; $\mathrm{L}=$ lever attached on the solenoids; $\bullet=$ Tygon groove to fit tubing; e = inner hole; $\mathrm{A}=$ inside view of the central piece; and $\mathrm{h}=$ lead hole for the screw. The injector body was fixed on a perspex plate with $25 \times 20 \times 1 \mathrm{~cm}$ by means of screws threaded in b. Plates 1,2 and 3 were assembled side by side with screws placed through the hole $\mathrm{c}$ and threaded in the screw thread $\mathrm{f}$. for iron (III)/ iron (II) speciation should present a physical structure quite different, the injectors were machined in the same way.

In the flow diagram depicted in Fig. 2, the injector is in the sampling position. The valves $\mathrm{V}_{1}$ and $\mathrm{V}_{2}$ are switched off, the sample solution flows through the sampling loop towards waste and the chromogenic reagent $\left(\mathrm{R}_{3}\right)$ is pumped back to its reservoir vessel. The resin column (c) is aligned with the flow line of the potassium peroxydisulphate solution $\left(\mathrm{R}_{2}\right)$, allowing the resin to be loaded with peroxydisulphate anions. When the microcomputer sends a set of electric pulses to $V_{1}$ solenoid valve as indicated in valve timing course, the valve undergoes a sequence of on/off switching. Under this condition, sampling loop (L) is loaded with a string formed of sample (S) slugs in tandem with slugs of triethanolamine $\left(\mathrm{R}_{1}\right)$.

The injection step starts when the microcomputer sends an electric pulse to solenoid attached to central sliding bar of injector, displacing it to injection position. In the new position, sampling loop and resin column are inserted in the same pathway and carrier solution flows through them. Under this condition, the analyte ions are transported by carrier solution through the resin column towards the junction point $\mathbf{x}$. As indicated in the valves timing course, microcomputer waits $3 \mathrm{~s}$ delay time, then sends an electric pulse to $V_{2}$ valve to add an aliquot of chromogenic reagent $\left(R_{3}\right)$ to sample zone. Mixing and chemical reactions occur inside reaction coil $\left(\mathrm{B}_{2}\right)$ while sample zone is displaced

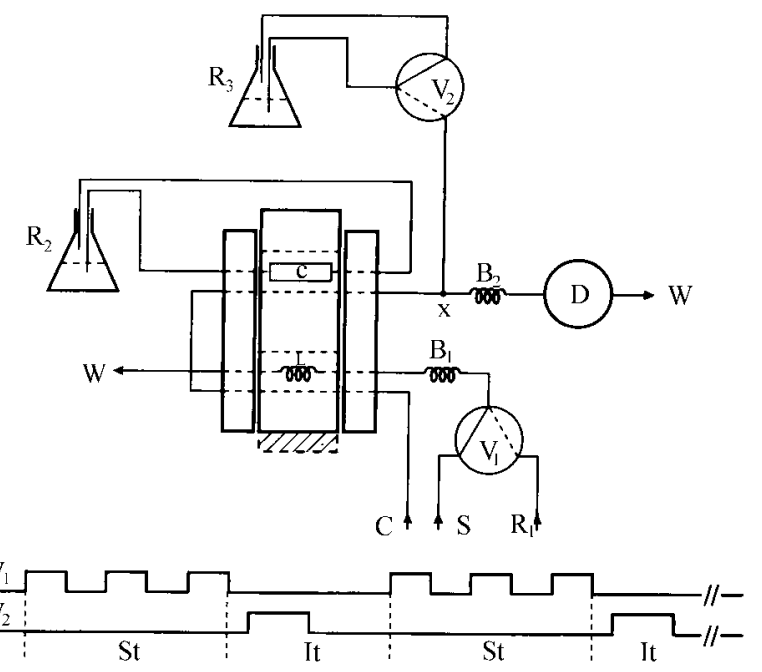

Figure 2. Diagram of the flow system for nickel determination. $V_{1}$ and $\mathrm{V}_{2}=$ solenoid valves; $\mathrm{S}=$ sample solution; $\mathrm{R}_{1}=$ triethanolamine solution, at $2.0 \mathrm{~mL} \mathrm{~min}^{-1} ; \mathrm{C}=$ sample carrier, $0.5 \mathrm{~mol} \mathrm{~L}^{-1} \mathrm{HCl}$ solution, at $2.5 \mathrm{~mL} \mathrm{~min}^{-1} ; \mathrm{B}_{1}$ and $\mathrm{B}_{2}=$ reaction coils, 10 and $100 \mathrm{~cm}$ length respectively; $\mathrm{L}=20 \mathrm{~cm}$, sampling loop; $\mathrm{x}=$ confluence point; $\mathrm{W}=$ waste; $\mathrm{c}=$ resin column $(10 \mathrm{~mm}$ long, $5 \mathrm{~mm}$ i.d. $) ; \mathrm{R}_{2}=$ peroxydisulphate solution, at $2.0 \mathrm{~mL} \mathrm{~min}^{-1} ; \mathrm{R}_{3}=$ dimethylglyoxime solution, at $1.6 \mathrm{~mL} \mathrm{~min}^{-1}$; $\mathrm{D}=$ spectrophotometer at $460 \mathrm{~nm} ; \mathrm{TV}_{1}$ and $\mathrm{TV}_{2}=$ timing course for $\mathrm{V}_{1}$ and $\mathrm{V}_{2}$ valves; $\mathrm{St}=$ sampling step; and $\mathrm{It}=$ injection step. The high levels indicate that the respective valve is switched on. 
towards detector by carrier solution (C). After the analytical signal is recorded, microcomputer sends an electric pulse to the other solenoid in order to displace sliding bar back the sampling position. The next analytical cycle starts when the microcomputer sends a set of electric pulses to $\mathrm{V}_{1}$ valve. The time interval to switch $\mathrm{V}_{1}$ valve on/off was varied from 0.1:0.2 up to 0.8:0.2 s in steps of $0.1 \mathrm{~s}$. The number of pulses was enough to load the sampling loop (L) with the string of sample and triethanolamine solutions.

Dimethylglyoxime is a widespread reagent for spectrophotometric determination of nickel. However it reacts also with iron ions forming a compound which absorbs at the same wavelength range observed for the nickel compound, thus causing strong interference ${ }^{4}$. To overcome this drawback, a triethanolamine solution was used as masking reagent, added to the sample bulk during the sampling step, by employing the binary sampling approach ${ }^{17}$. Under this condition, the reaction coil $\left(\mathrm{B}_{1}\right)$ is loaded with a string comprising slugs of sample in tandem with slugs of triethanolamine. While the string is transported towards waste $(\mathrm{W})$ through this reaction coil and sampling loop $(\mathrm{L})$, mixing occurs between sample and reagent slugs, providing facilities for masking reaction to occur in the sampling step.

The lengths of the mixing coil and sampling loop were fixed at 10 and $20 \mathrm{~cm}$, since the length of the slugs may exert a remarkable effect on the mixing level attained inside the sampling loop (L). In order to find the best conditions for the complex formation of the iron, the $\mathrm{V}_{1}$ valve on/off ratio was varied from 0.5 to $4.0 \mathrm{~s}$ in steps of $0.1 \mathrm{~s}$, maintaining the time interval for position on, at $0.2 \mathrm{~s}$. After loading the sampling loop with sample plus masking solu-
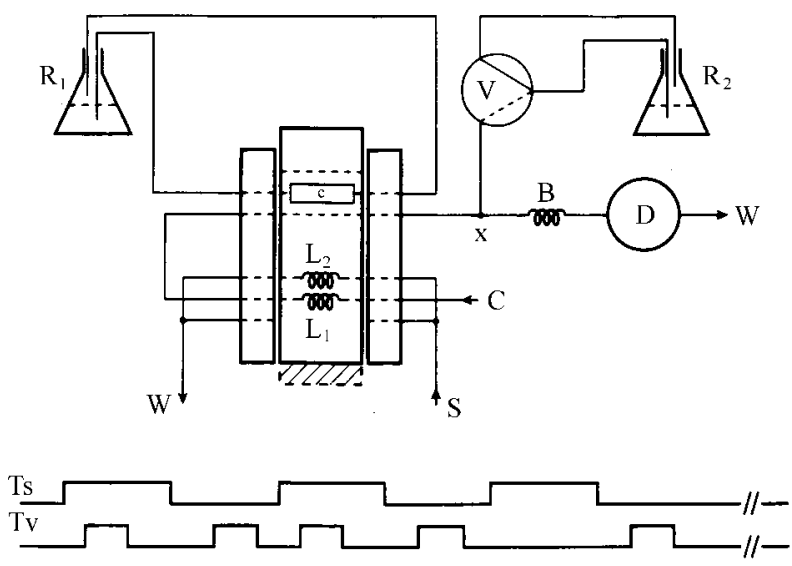

Figure 3. Diagram of the flow system for iron speciation. $\mathrm{S}=$ sample solution $2.0 \mathrm{~mL} \mathrm{~min}^{-1} ; \mathrm{C}=$ sample carrier stream, $0.014 \mathrm{~mol} \mathrm{~L}^{-1} \mathrm{HNO}_{3}$ solution, at $2.5 \mathrm{~mL} \mathrm{~min}^{-1} ; \mathrm{L}_{1}$ and $\mathrm{L}_{2}=50 \mathrm{~cm}$, sampling loops; $\mathrm{R}_{1}=$ peroxydisulphate solution, at $2.0 \mathrm{~mL} \mathrm{~min}^{-1} ; \mathrm{R}_{2}=$ potassium thiocyanate solution, at $1.6 \mathrm{~mL} \mathrm{~min}^{-1}, \mathrm{~B}=$ helicoidal reaction coil, $100 \mathrm{~cm}$ length; $\mathrm{D}$ $=$ spectrophotometer at $495 \mathrm{~nm}$; Tv and $\mathrm{Ts}=$ timing course of the solenoid valve $\mathrm{V}$ and of the injector sliding bar, respectively. Other symbols as in Fig. 2. tion mixture, $\mathrm{V}_{1}$ valve was switched off to save masking reagent.

The flow diagram in Fig. 3 was designed to perform speciation of iron (III)/iron (II). In the position specified, sample solution (S) is flowing through the sampling loop $\left(\mathrm{L}_{2}\right)$ towards waste $(\mathrm{W})$ and the peroxydisulphate solution $\left(R_{1}\right)$ is pumped through resin column, and returning to its reservoir. The sample aliquot previously collected by sampling loop $\left(\mathrm{L}_{1}\right)$ is transported by carrier solution $(\mathrm{C})$ towards the confluence point $\mathbf{x}$, where an aliquot of potassium thiocyanate solution $\left(\mathrm{R}_{2}\right)$ is added to the sample zone by switching the solenoid valve (V) as indicated in the sampling timing course. Sample and reagent solution mixing, as well as the chemical reaction occur in the reaction coil (B). The signal generated by detector (D) is then related to iron (III) content. After recording analytical signal, microcomputer sends an electric pulse to solenoid in order to displace the sliding bar of the injector to other position. The sample aliquot collected in previous step by the sample loop $\left(\mathrm{L}_{2}\right)$ is transported by carrier solution through the resin column (c) where iron (II) ions are oxidized to iron (III) by peroxydisulphate anions retained in the resin column. Chromogenic reagent addition, detection and signal recording are carried out as for iron (III) determination and analytical signal is related to iron(III) plus iron(II) contents in the sample.

\section{Results and Discussion}

\section{Nickel determination}

As depicted in the flow diagram of Fig. 2, the sampling loop was loaded with a string formed with slugs of sample in tandem with slugs of masking solution. Better results were obtained when the valve switching on/off ratio was 0.4:0.2 s $(1.7 \mathrm{~Hz})$. Under this condition, the volumes of the slugs were 6.7 and $13.3 \mu \mathrm{L}$ (13.4 and $26.6 \mathrm{~mm}$ length) for sample and for masking reagent solutions, respectively, since sampling flow rate was $33.3 \mu \mathrm{L} \mathrm{s}^{-1}$. Additional experiments were performed by using a $30.0 \mathrm{mg} \mathrm{L}^{-1}$ nickel plus $200 \mathrm{mg} \mathrm{L}^{-1}$ iron standard solution. It was observed that for valve switching on/off ratios lower than 0.4:0.2 s, the iron interference was not fully suppressed. On other hand, ratios higher than 0.4:0.4 s resulted in lowering of analytical signal, presumably because of the sample dilution. Therefore, the valve switching on/off ratio 0.4:0.2 s was employed in further experiments.

The reaction of nickel with dimethylglyoxime occurs also without adding the oxidizing reagent, but the time interval required to complete the chemical reaction was higher than 14 min (Fig. 4). Otherwise, employing the resin column with peroxydisulphate ions, a time interval of $25 \mathrm{~s}$ was enough to complete $70 \%$ of the chemical reaction. By decreasing the carrier flow rate from 2.5 to $1.6 \mathrm{~mL} \mathrm{~min}^{-1}$, the sample residence time interval was incremented in 
about $40 \%$. Under this condition, the recorded signal reached the maximum value, indicating that chemical reaction was completed in approximately $40 \mathrm{~s}$. The peak shapes $\mathbf{A}^{\prime}$ and $\mathbf{B}$ show that peroxydisulphate exerts a remarkable effect on the kinetics of the chemical reactions. The recorder tracings $\mathbf{b}$ and $\mathbf{c}$ indicate a good reproducibility and stability of the peak shapes, when the resin column was utilized.

As illustrated in Fig. 2, the peroxydisulphate solution was pumped to circulate through the resin column. Therefore, in sampling step the oxidizing ions consumed by reaction in injection step are replaced. However, consecutive measurements using a $30.0 \mathrm{mg} \mathrm{L}^{-1}$ nickel standard solution, and $5 \%$ peroxydisulphate solution $(10 \mathrm{~mL})$ showed that after 50 consecutive injections, a continuous decrease in the signal magnitude was observed. As the carrier stream was a $0.5 \mathrm{~mol} \mathrm{~L}^{-1} \mathrm{HCl}$ solution, chloride ions could be absorbed by resin in injection step replacing peroxydisulphate ions. When the injector sliding bar was moved to sampling position, an inverse process occurred, increasing chloride concentration in circulating solution. After several analytical cycles, chloride concentration became high enough to cause competition with peroxydisulphate ions by resin active sites. As a result, a drop in analytical signal was observed, since the kinetics of the chemical reaction depends strongly on peroxydisulphate concentration $^{5}$. In order to prevent this drawback, peroxydisulphate solution was changed after that number of analytical cycles. This approach was profitable, improving the kinetics of chemical reaction with a consumption of $10 \mathrm{mg}$ $(200 \mu \mathrm{L})$ peroxydisulphate per determination.

In order to save chromogenic reagent, the dimethylglyoxime solution was added by switching on the $\mathrm{V}_{2}$ valve only when the sample zone was crossing the joint point $\mathbf{x}$

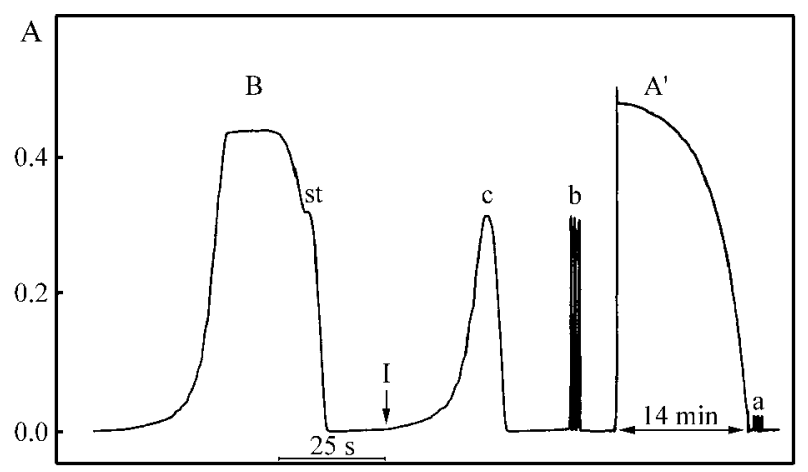

Figure 4. Effect of the peroxydisulphate concentration. A = absorbance; a and $\mathrm{A}^{\prime}=$ recording of the signals obtained by replacing the resin column (Fig. 2) by a loop and the peroxydisulphate solution by the carrier solution, for A' the peristaltic pump was stopped when the higher concentrated portion of the sample zone was inside of the flow cell; b, c and B = recorder tracing obtained when sample solution flows through the resin column loaded with peroxydisulphate ions; $\mathrm{I}=$ instant when injector sliding bar was displaced to injection position; $\mathrm{st}=$ stopping the peristaltic pump. Figure refers to a $10.0 \mathrm{mg} \mathrm{L}^{-1}$ nickel standard solution.
(Fig. 2). Maintaining this valve at the position on for $5 \mathrm{~s}$ was enough to ensure a suitable distribution of the dimethylglyoxime throughout the bulk of sample zone. Then, considering that flow rate was $1.6 \mathrm{~mL} \mathrm{~min}^{-1}$, the reagent consumption per reading was $8.0 \mu \mathrm{g}(133 \mu \mathrm{L})$. This value correspond to $11 \%$ of the presumable consumption if a continuous pumping flow were used as in an usual flow system.

Once settled the experimental variables, the feasibility of the proposed approach was ascertained by running a set of steel alloy samples, also analyzed by FAAS, being results showed in Table 1. The accuracy was assessed by applying paired $t$-test and no significant difference at the 95\% confidence level between the results of the proposed method and those of the FAAS was observed. Other profitable features such as a throughput of 80 measurements per hour and a relative standard deviation $(\mathrm{n}=10)$ of $1 \%$ for a typical sample $21.5 \%(\mathrm{~m} / \mathrm{m}) \mathrm{Ni}$ were achieved. For the proposed working condition, a detection limit of $3.1 \mathrm{mg}$ $\mathrm{L}^{-1}$ was estimated, this value should be improved by increasing the volume of the sample aliquot.

Table 1. Results of the steel alloys analyzes.

\begin{tabular}{lcc}
\hline Sample & $\begin{array}{c}\text { Proposed method } \\
(\% \mathrm{~m} / \mathrm{m})\end{array}$ & $\begin{array}{c}\text { FAAS } \\
(\% \mathrm{~m} / \mathrm{m})\end{array}$ \\
\hline 1 & $23.0 \pm 0.2$ & $20.9 \pm 0.2$ \\
2 & $22.0 \pm 0.2$ & $22.2 \pm 0.2$ \\
3 & $21.8 \pm 0.2$ & $22.1 \pm 0.2$ \\
4 & $19.3 \pm 0.2$ & $20.4 \pm 0.2$ \\
5 & $22.5 \pm 0.2$ & $23.1 \pm 0.2$ \\
6 & $20.2 \pm 0.2$ & $20.7 \pm 0.2$ \\
\hline
\end{tabular}

Mean values with uncertainties based on 3 consecutive measurements.

\section{Iron speciation}

When the resin column was inserted into the analytical path, its physical structure was changed and, as a consequence, the dispersing effect underwent an increase caused by the resin dead volume. As shown in Fig. 5, the analytical signal decreased in about $20 \%$, and time interval to run the injection step and to record the analytical signal was increased in $30 \%$.

When the peroxydisulphate solution was not recycled through the column, a continuous drop in the analytical response was observed after the third measurement (Fig. 6 ). This drop could be avoided by pumping a $5.0 \%$ peroxydisulphate solution through the column while the sampling loop was loaded. In this case, recycling $10 \mathrm{~mL}$ peroxydisulphate solution as indicated in Fig. 3, up to 80 consecutive measurements could be performed without any observable loss in the analytical response. 
When the resin column was inserted in the analytical path, its dead volume causes a increasing in the dispersion, that should be considered to ascertain oxidizing efficiency. This effect was verified by injecting an iron (III) solution and the results are shown in Fig. 5. The peak profile $\mathbf{b}^{\prime}$ is broader and lower than a', indicating that the dispersion

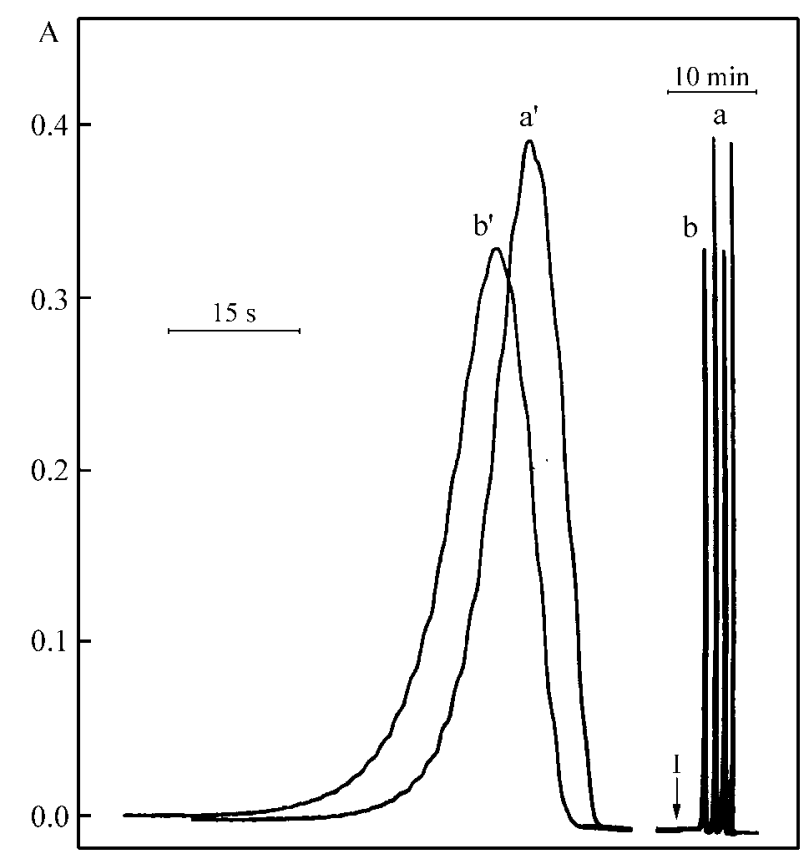

Figure 5. Dispersing effect of the resin column. $A=$ absorbance; $I=$ instant when sliding bar of injector was displaced to injection position; a and $\mathrm{a}^{\prime}=$ recorder tracings of analytical signal generated with the resin column outside of the analytical path; $b$ and b' = recorder tracings obtained with standard solution flowing through the resin column. The figure refers to $10.0 \mathrm{mg} \mathrm{L}^{-1}$ iron (III).

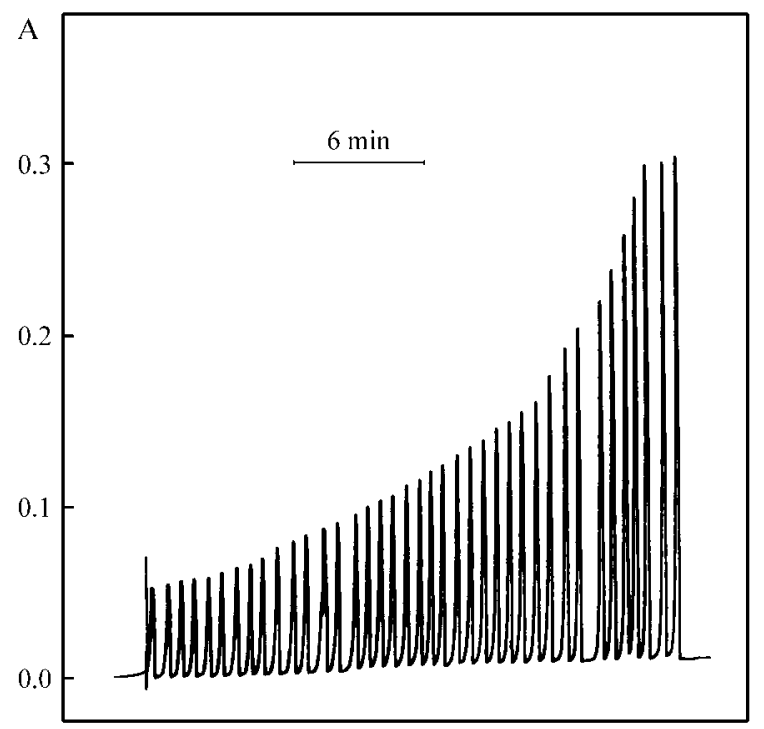

Figure 6. Oxidizing efficiency with replicate number. $A=$ absorbance. Figure refers $10.0 \mathrm{mg} \mathrm{L}^{-1}$ iron (II) standard solution. For details see results and discussion section. caused by the resin column dead volume was about $20 \%$. This value was calculated considering the ratio of the peak's height (b/a).

The ability of the immobilized reagent to oxidize iron (II) was verified by injecting alternately standard solutions (10.0 $\mathrm{mg} \mathrm{L}^{-1}$ ) of iron (II) and of iron (III) and an oxidizing efficiency of about $99 \%$ was observed. To find this result the dispersion effect caused by the resin column as indicated in Fig. 5 was considered.

To ascertain the feasibility of proposed system, a set of river water samples was analyzed, and the results are shown in Fig. 7 and Table 2. The slope of analytical curve related to iron (II) is lower than that observed for iron (III), probably caused by the increase in the dispersion due to the resin column. One can deduce from this figure, that a sample throughput of 60 determination per hour was achieved.

In the proposed approach iron (II) concentration was determined by subtracting iron (III) from total iron. Then, to ascertain accuracy a set of water samples was also analyzed for iron (II) utilizing 1,10-phenantroline spectrophotometric method and results are shown in Table 3. By applying the paired $t$-test between the results of the proposed procedure and these of the FAAS (Table 2) and 1,10-phenantroline spectrophotometric method, no significant differences at $95 \%$ confidence level were observed. Other profitable features such as a relative standard deviation of $1.5 \%$ for a typical iron (III) sample with $3.17 \mathrm{mg} \mathrm{L}^{-1}$ $(\mathrm{n}=10)$, a reagent consumption of $3.5 \mathrm{mg}(70 \mu \mathrm{L})$ peroxydisulphate solution, $5.4 \mathrm{mg}(270 \mu \mathrm{L})$ potassium thiocyanate solution and detection limits of $0.4 \mathrm{mg} \mathrm{L}^{-1}$ for iron (III) and total iron were estimated.

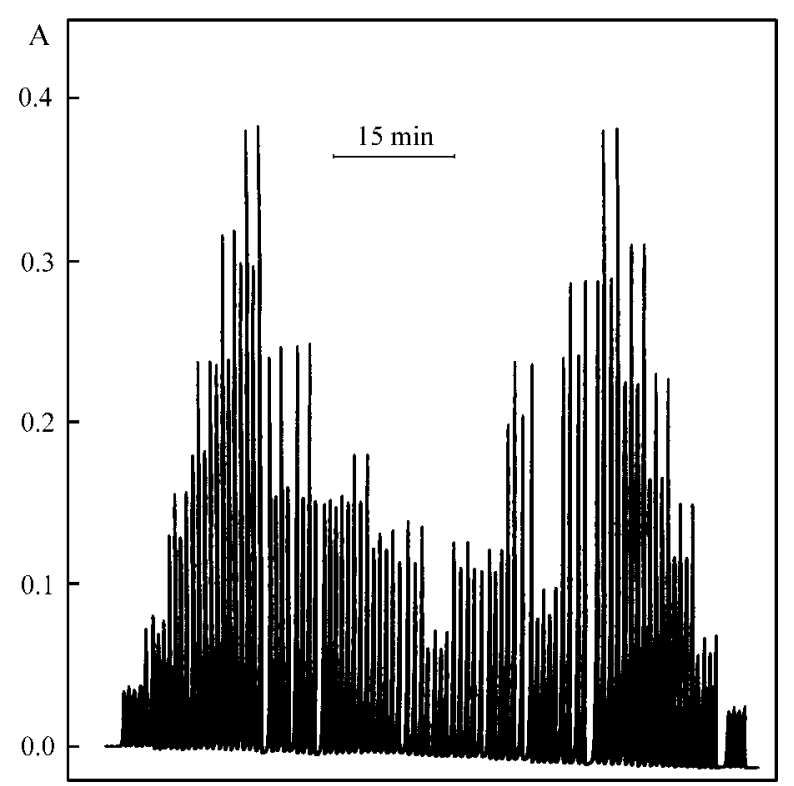

Figure 7. Recorder tracing of a routine run. From left, iron (II) 0.00 , 1.00, 2.00, 4.00, 6.00, 8.00, $10.0 \mathrm{mg} \mathrm{L}^{-1}$ and iron (III) standard solutions, followed by 12 samples and again the standard solutions, all in duplicate. 
Table 2. Results of the water analyzes.

\begin{tabular}{lcccc}
\hline Sample & \multicolumn{3}{c}{ Proposed method $\left(\mathrm{mg} \mathrm{L}^{-1}\right)$} & \multirow{2}{*}{ FAAS $\left(\mathrm{mg} \mathrm{L}^{-1}\right)$} \\
\cline { 2 - 5 } & $\mathrm{Fe}^{3+(a)}$ & $\mathrm{Fe}^{3+}+\mathrm{Fe}^{2+(b)}$ & $\mathrm{Fe}^{2+(*)}$ & $7.45 \pm 0.07$ \\
2 & $7.49 \pm 0.07$ & $8.36 \pm 0.08$ & $0.87 \pm 0.11$ & $2.55 \pm 0.03$ \\
3 & $2.62 \pm 0.03$ & $2.76 \pm 0.04$ & $0.14 \pm 0.05$ & $6.40 \pm 0.05$ \\
4 & $6.08 \pm 0.03$ & $6.20 \pm 0.04$ & $0.12 \pm 0.05$ & $3.41 \pm 0.02$ \\
5 & $3.17 \pm 0.03$ & $3.64 \pm 0.03$ & $0.47 \pm 0.04$ & $4.20 \pm 0.03$ \\
6 & $2.86 \pm 0.02$ & $4.38 \pm 0.03$ & $1.52 \pm 0.04$ & $1.95 \pm 0.01$ \\
8 & $1.96 \pm 0.01$ & $1.97 \pm 0.01$ & $0.01 \pm 0.01$ & $3.52 \pm 0.02$ \\
9 & $3.51 \pm 0.04$ & $3.48 \pm 0.03$ & $0.03 \pm 0.05$ & $3.86 \pm 0.03$ \\
10 & $3.33 \pm 0.02$ & $4.03 \pm 0.02$ & $0.70 \pm 0.03$ & $4.67 \pm 0.03$ \\
\hline
\end{tabular}

Mean values with uncertainties based on 3 consecutive measurements.

*Iron (II) concentrations were calculated by subtracting data of column $a$ from column $b$.

Table 3. Results of iron (II) in waters samples.

\begin{tabular}{lcc}
\hline Sample & $\begin{array}{c}\text { Proposed method } \\
\left(\mathrm{mg} \mathrm{L}^{-1}\right)\end{array}$ & $\begin{array}{c}1,10-\text { phenantroline } \\
\left(\mathrm{mg} \mathrm{L}^{-1}\right)\end{array}$ \\
\hline 1 & $0.91 \pm 0.03$ & $0.87 \pm 0.02$ \\
2 & $13.1 \pm 0.0$ & $11.9 \pm 0.0$ \\
3 & $5.47 \pm 0.02$ & $5.88 \pm 0.03$ \\
4 & $4.18 \pm 0.07$ & $4.25 \pm 0.02$ \\
5 & $6.02 \pm 0.05$ & $6.93 \pm 0.04$ \\
\hline
\end{tabular}

Mean values with uncertainties based on 3 consecutive measurements.

\section{Acknowledgments}

The authors would like to thank Dr. E.A.G. Zagatto for comments and FAPESP (Fundação de Amparo à Pesquisa do Estado de São Paulo), CNPq (Conselho Nacional de Desenvolvimento Científico e Tecnológico), CAPES (Coordenadoria de Aperfeiçoamento de Pessoal de Nível Superior) for financial support.

\section{References}

1. Kragten, J.; Parczenski, A. Talanta 1981, 28, 901.

2. Murakami, M.; Takada, T. Talanta 1992, 39, 1293.

3. Fu-Sheng, W.; Pei-Hua, Q.; Nai-Kui, S.; Fang, Y Talanta 1981, 28, 189.

4. Marczenko, Z. In Separation and Spectrophotometric Determination of Elements, John Wiley \& Sons, New York, 1986, p 393.
5. Martelli, P.B.; Reis, B.F.; Kronka, E.A.M.; Bergamin Filho, H.; Korn, M.; Zagatto, E.A.G.; Lima, J.L.F.C.; Araújo, A.N. Anal. Chim. Acta 1995, 308, 397.

6. Calatayud, J.M.; Mateo, J.V.G. Chem. Anal. 1993, 38, 1.

7. Giné, M.F.; Bergamin Filho, H.; Zagatto E.A.G.; Reis, B.F. Anal. Chim. Acta 1980, 114, 191.

8. Faria, L.C.; Pasquini, C.; Oliveira Neto, G. Analyst 1991, 116, 357.

9. Calatayud, J.M.; Mateo, J.V.G. Trends Anal. Chem. 1993, 12, 428.

10. Ruzicka, J.; Andal, A. Anal. Chim. Acta 1989, 216, 243.

11. Malamas, F.; Bengtsson, M.; Johnsson, G. Anal. Chim. Acta 1984, 160, 1.

12. Reis, B.F.; Martelli, P.B.; Krug, F.J.; Tumang, C.A. J. Braz. Chem. Soc. 1992, 3 (1\&2) 38.

13. Hwang, H.; Dasgupta, P.K. Anal. Chem. 1987, 59, 1356.

14. Bysouth, S.R.B.; Tyson, J.F.; Stockwell, P.B. Anal. Chim. Acta 1988, 214, 329.

15. Faizullah, A.T.; Townshend, A. Anal. Chim. Acta 1985, 167, 225.

16. American Public Health Association, American Water Works and Water Pollution Control Federation, Standard Methods for the Examination of Water and Wastewater, American Public Health Association, Washington, 1976, p. 207.

17. Reis, B.F.; Giné, M.F.; Zagatto, E.A.G.; Lima, J. L. F. C.; Lapa, R.A. Anal. Chim. Acta 1994, 293, 129. 